\title{
How Do Primary Schoolchildren Use Concept Definitions in Recognition Tasks? Orientation Towards Given Knowledge in Two Different Educational Systems
}

\author{
Anastasia N. Sidneva ${ }^{a^{*}}$, Elena V. Vysotskaya ${ }^{b}$, Irina V. Korotaeva ${ }^{a}$, \\ Igor L. Mozharovsky ${ }^{\text {a }}$, Valeria A. Shinelis ${ }^{a}$ \\ ${ }^{a}$ Lomonosov Moscow State University, Moscow, Russia \\ ${ }^{b}$ Psychological Institute of Russian Academy of Education, Moscow, Russia \\ * Corresponding author. E-mail: asidneva@gmail.com
}

Introduction The need to develop students' ability to learn independently has been a widely discussed issue in the theory and practice of education over the past 50 years (in research on learning to learn, self-regulated learning, metacognitive learning, etc.). If we understand instruction as a system of activities by the student and teacher, associated primarily with the transmission of cultural experience, then studying the psychological mechanism for accepting and using the proffered knowledge as an orientation for future actions is highly relevant.

Objective. We surmised that the ability to use given knowledge in the school instruction process (which we call "orientation towards given knowledge" [OGK]) would differ between fourth-graders studying in traditional educational systems (TE) and those in Developmental Education (DE), since these systems differ significantly in the principles of the selection learning material and organization of learning activity. We also sought to clarify the correlation between OGK and such important educational outcomes as the ability to identify the most important thing in a text, logical skills, memorization skills, and academic achievement.

Design. To diagnose OGK, we gave fourth-graders $(\mathrm{N}=115)$ the definition of a concept, an instruction to recognize and identify objects as either being described or not described by that concept, and 10 recognition problems in the form of short texts. We assessed the level of OGK by counting the number of problems for which the answer was justified by the given definition. In addition, we measured the ability to identify the main point in the text, logical skills, and random memorization skills.

Results. Almost a quarter of all the fourth-graders (25.7\%) failed to use the given definition at all; however, the DE students demonstrated a higher level of OGK $(U=2038, p<.01)$ significantly more often. OGK among general sample also correlated with the ability to identify the most important thing in a text $(R=0.31$, $\mathrm{p}<.001)$, logical skills $(\mathrm{R}=+0.35, \mathrm{p}<.001)$, and memorization skills $(\mathrm{R}=+0.195$, $\mathrm{p}<.05$ for short-term memory and $\mathrm{R}=+0.301, \mathrm{p}<.01$ for long-term memory).

Conclusions. Possible reasons for the cognitive performance of the fourth-graders are discussed. We argue that orientation towards given knowledge can be considered an essential condition for effective learning, and therefore serious attention should be paid to its development.

Keywords:

Activity approach, Developmental Education, action, recognition action, orientation towards given knowledge 


\section{Introduction}

The problem of students not applying the knowledge they have gained to solving problems is one of the key ones in pedagogical psychology and educational practice (Barnett \& Ceci, 2002; Vosniadou, 2013; Zukerman \& Ermakova, 2004).

In Bloom's widely known taxonomy of learning tasks (1956), which was revised by L. Anderson and D. Krathwohl (Anderson \& Krathwohl, 2001), the authors describe six educational goals that the teacher should achieve: to remember, to understand, to apply, to analyze, to evaluate, and to create. The student must first remember and understand, and only after that learn to apply this "knowledge" to solving problems. The teacher's task in the first two grades is to ensure the "acquisition of knowledge" as such, whereas how it can be used, how the limits of its applicability can be analyzed and evaluated, serves only in an explanation of the role that the acquisition of knowledge should play in the next stages of the learning process.

In the Activity Approach to the learning process developed in Russian psychology and based on L.S. Vygotsky's ideas (Vygotsky, 1978; Leontiev, 2005; Gal'perin, 1989; Talyzina, 1975) a fundamentally different approach has been proposed to how given knowledge mediates problem solving. The main ideas of this approach were implemented in real educational practice, known as Developmental Education system, which emerged in the Soviet Union more than 60 years ago (Davydov, 1996, 1995; Zukerman \& Venger. 2010). How does this system work?

\section{The Activity Approach to Applying Given Knowledge to Problem Solving}

In Russian, the word "knowledge" (znanie) has two different meanings. There is knowledge considered as information that must be acquired through sociocultural experience, and knowledge that is the result of individual experience of an activity. We will use this term in the first sense: knowledge as a social and cultural experience that has to be learned. This distinction is described by L. Radford (2013), who suggested a clear difference between knowledge and knowing: Knowledge is a "historically and culturally codified fluid form of thinking and doing," which exists independently of the individual mind. But real knowledge ("knowing") is only real if it is the result of one's own activity (Radford, 2013, p. 16).

The Russian philosopher E.V. Ilyenkov (1991), addressing the differences between given knowledge and knowledge "possessed by the subject," writes: "[T]here is a serious reason to think that the very problem they are trying to solve in this way arises only because the 'knowledge' is given to a person in an inadequate form, or, to put it more crudely, is not real knowledge, but merely a surrogate..." (Ilyenkov, 1991, p. 381).

But what can be considered an adequate form of given knowledge in this case? According to the Activity Approach, developed in Russian psychology in the general framework of cultural-historical consideration of the psychological mechanisms of acquisition of knowledge, we should begin with an analysis of actions rather than of knowledge. It is important to choose actions in which the proffered knowledge can assume the role of a cultural mediator (in L.S. Vygotsky's terminology; see, e.g., Vygotsky, 1978) - i.e., the way of performing these actions will necessarily include the given knowledge as a component. What is action and how does it 
relate to knowledge obtained from a textbook, from the words of the teacher, and other sources?

Action [Russian: deistvie], according to P.Ya. Gal'perin (1989), is the leading component of the educational process: "For students, the learning process is a continuous sequence of actions: listening and understanding (the teacher's instructions and explanations), reading and writing, counting, adding and subtracting, performing grammatical, mathematic, and historical analyses, etc.); these are all different actions: intellectual, perceptual, verbal, and physical" (Gal'perin, 1989, p. 65). There is no precise English translation of the Russian term deistvie; it can be most closely translated as a purposeful action that leads to the solution to the particular problem.

Another component of the educational process are concepts that must be acquired through action or as part of different actions (Gal'perin, 1989). Gal'perin distinguishes between the content of concepts (mathematical, linguistic, etc.) and their psychological role in an action.

He states that from the psychological standpoint, we can speak of three components of any action: orienting (developing a goal, a plan for implementation, and tools for checking the results), executing, and controlling (Gal'perin, 1966). The main component of the orienting part is the orientation basis of action (OBA), which is what the subject actually focuses on when performing the action. OBA also includes an understanding of the goal (object) of an action, the sequence in which it is implemented, as well as the characteristics of the material (if it is physical action), the tools used, and much more (Gal'perin, 1989). Moreover, the actual OBA may contain significant discrepancies from the cultural norm associated with "given knowledge", making it possible to solve problems in this subject area without errors.

The task of any student is to achieve an OBA that will allow an independent solution of the specific problems presented. Cultural content is conveyed in school by educational texts, including presentations by the teacher, which contain definitions of the necessary concepts and other educational information "provided for the acquisition of knowledge". Most students do not have much success in extracting from these sources the points of orientation that are objectively necessary to grasp a concept (understanding the way its content can orient their own actions).

Gal'perin did not consider it promising to study how concepts are formed spontaneously. In his view, the genesis of mental processes (actions and concepts) should be that of systematic and stage-by-stage formation of mental actions and concepts (Gal'perin, 1966), by means of which, through creating conditions for actions of the necessary quality, we simultaneously clarify those conditions. One of the most important is the teacher's ability to choose a learning method that forms the first, second, or third type of orienting basis of action. In fact, only the second and third types of instruction promote the formation of knowledge as an orientation of action. What are these types?

The first type of OBA is mainly characterized by students' use of trial and error to orient their own actions. In the search for points of orientation, students may use completely different aspects of the learning situation (the teacher's explanation as coming from a "knowledgeable" person; demonstration of a model for solving spe- 
cific problems; description rather than definition of objects that are grouped into a concept; demonstration of a set of objects for independent comparison and identification of "essential" attributes, etc.). The student's gradually developing OBA usually contains some attributes that are insignificant for the particular concept, unsuitable for solving this class of problems, operations, etc. For example, if the teacher suggests to students only the definition of "perpendicular lines", and then gives them problems that require the recognition of perpendicular lines (actions of recognition), the students will have to independently find a way to perform such actions. N.F. Talyzina (Talyzina, 1975) distinguished three operations in the action of recognition: (a) identification of attributes (if a definition is given, the attributes have to be "extracted" from it); (b) identification of their presence (or absence) in each object presented; (c) a conclusion about whether an object belongs or does not belong to this class of objects, according to a logical rule.

First of all, students should select the relevant characteristics of the perpendicular lines from the definition: (a) two lines (in fact, two characteristics - they should be lines and there should be two of them); (b) both should be straight; (c) the angle between them should equal 90 degrees. Secondly, students need to be able to identify each characteristic in the objects presented to them, and, finally, to draw a conclusion (are they perpendicular lines or not, or do we need more information?), using a logical rule. Most children have a hard time doing all this independently, so their OBA is incomplete and very concrete.

In their classic article, Gal'perin and Talyzina (1957) criticized the practice of using of the first type of OBA and proposed another method of teaching, which makes it possible to provide the student with the means and methods of action of an appropriate quality and to make the given knowledge a real point of orientation for future actions. First of all, the authors contend that the definition of objects related to the concept, unlike their description, should be appropriately "operationalized". This means that it should include attributes that can be used to establish their presence or absence in each object, when a student performs an "action of recognition".

Such instruction, which results in the second type of OBA, gives the students a complete system of points of orientation and operations within the required class of tasks, in a finished form, as a "method of action". Searching for them independently, by trial and error, is therefore not a relevant task for the student. The teacher's task is to encourage the use of a given set of operations and their points of orientation for solving every task. This makes the proposed method a real instrument for executing an action under specific conditions, while variations in the types of problems make it possible to test the method under different conditions (and thereby to make it a real point of orientation).

Development of actions according to the third type of OBA, in turn, makes it possible to arm students with a "method of analysis" of the objective situation, so as to independently construct a way to solve the problem under the given changing, specific conditions (Gal'perin, 1966; Davydov, 1996; Ilyenkov, 1991). Instruction by this general method is a special action of educational research, as a result of which students should establish for themselves an objective connection between the given knowledge and its orienting content. The "generation" of such knowledge through action should be constructed on the basis of special "logical-genetic" reconstruc- 
tion of the process by which a concept emerges (Davydov, 1996). This makes it possible to set tasks not only for qualitative mastery, but also for development of conceptual thinking, as the student and teacher move forward together through the subject matter.

Thus, in the Activity Approach, the main question is not what "methodological techniques" may be taught, to apply already "mastered" knowledge in practice, but rather how to find the necessary actions (since by no means all actions to which the given knowledge might be applied are suitable), how to implement them in educational practice, how to make the given knowledge a real point of orientation and means toward these actions from the outset - i.e., how to encourage students to use that knowledge and how to ensure their mastery or interiorization of these actions (Gal'perin, 1966).

\section{The Concept of "Orientation Towards Given Knowledge" (OGK)}

Gal'perin addresses the study of the psychological mechanisms of learning: "The construction of a process with certain properties that are possible only under certain conditions, allows us to find out these conditions. This constitutes the main, or, rather, the leading, method of studying these psychological phenomena. Only later, when the way to achieve this has been established, does the possibility arise of analysis and assessment of real phenomena" (Gal'perin, 1998, p. 288). In our view, the general mechanisms of analysis and assessment of real phenomena were not fully established by Gal'perin and the Activity Approach, and his method of systematic stage-by-stage formation made it possible to determine only specific conditions of the formation of specific subject-specific actions (see Sidneva, 2016). For example, the general principles of the formation of new concepts and actions did not become a real tool for assessing the effectiveness of different educational practices, although attempts to do this are being made (Stepanova, 2005; Lvovsky et al., 2015).

One of the conditions identified by Gal'perin as key for effective instruction is the relationship to given knowledge as an orientation for action. The student's ability to grasp educational information in its orientation function is what we called "orientation towards given knowledge" (OGK).

We suggest that orientation towards given knowledge consists of two interconnected components:

1. The ability to perceive given knowledge (a text, a definition, a formula, etc.), as an instrument (a mediating tool) for certain actions (what questions it can answer, what problems a student can solve with it, etc.);

2. The ability to use the given knowledge (a text, a definition, a formula, etc.), rather than other knowledge, in solving these problems.

To diagnose OGK, we chose the above-mentioned task of recognizing objects that were described by the definition of a concept. What was the reason for our choice?

In a recognition action, the attributes specified by the definition can become real points of orientation, and the definition itself can play the role of a recognition "tool" (or it may not, and recognition will be mediated by something else). Thus, 
a fairly simple diagnostic situation can be constructed. And finally, the absence of errors in recognition indicates that the given definition (as knowledge of essential attributes) is being used correctly in its orienting function.

So, for example, Gal'perin and Talyzina (1957) in their early works - on which we based ourselves when we chose a diagnostic situation - described children who, as a result of a formative experiment, performed a generalized recognition action, then examined any new concept from the point of view of a future recognition action: whether these attributes would allow objects to be recognized (for example, they might criticize a given definition if it did not allow the recognition of objects). "The aim of instruction as a specific social process," writes Talyzina, "is not to encourage the child to rediscover this system of signs that was discovered long ago, but to use them as a model for 'looking' at objects ... from the standpoint that is represented in this concept" (Talyzina, 1975). The recognition action, described in detail in many works of the Gal'perin school as a psychological mechanism mediating the recognition of objects by a given definition (as "knowledge" about the object's essential attributes), may turn out to be appropriate for analyzing the formation of the orienting functions of concepts in schoolchildren.

\section{Possible Differences in OGK Among Students from Two Different Educational Systems}

Study of the conditions and quality of the formation of new concepts and activities can become a tool for evaluating the effectiveness of different educational systems. By "educational system", we mean a set of educational principles and strategies that relate to goals, content, methods, forms of education (teaching), as well as grading systems.

The Developmental Education (DE) system of D. B. El'konin and V. V. Davydov (El'konin, 1966; Davydov, 1996) can be considered as application of the Activity approach to educational practice. The main differences between DE and the contemporary traditional education system (TE) concern, first of all, the type of given knowledge that constitutes the subject matter (these are theoretical concepts in DE and empirical ones in TE) and the way children's actions are organized (learning activity).

The foundations of the DE system, as Davydov wrote, are very close to the third type of OBA (Davydov, 1996), which gives students the opportunity to take in all the given knowledge necessary to solve specific problems. Instruction that tries to focus on the third type of OBA was organized so that the attributes put forward in the definition of the concept are not just part of the method of problem solving, but the students would also realize the need to use only these attributes and not others. This was due to the students' conscious assimilation of the functions of the these concepts in the whole system. The definition of such a function was the goal of a specific orienting action, which was called a "learning task" in El'konin's and Davydov's theory of Developmental Education (Davydov, 1996; Zukerman \& Venger, 2010). For example, in studies by L.I. Aydarova (Aydarova, 1968), learning to distinguish a morpheme was based not only on its formal features (a prefix, suffix, etc.), but also on their "functional" meaning in conveying a specific message. These and other results were summarized by Gal'perin: The main goal of a teacher 
who is trying to use the third type of OBA is to convey the function of a set of objects that the concept expresses (Gal'perin, 1966).

In curricula based on DE principles, most concepts are proposed as means of performing certain actions (Davydov, 1996). On the other hand, active and problem-oriented methods of instruction are widely used in DE, when teachers encourage students to independently seek new knowledge (Zuckerman \& Venger, 2010). An interesting question, therefore, is whether students from the DE system will use given knowledge to solve problems more often and differently than TE students, and whether they will better recognize its orienting purpose.

Studies have shown that certain differences in cognitive and personality characteristics can be detected between DE and TE students, especially after fourth grade: DE students have better self-regulation (Repkina, 1997; Morosanova, Aronova, 2004); some cognitive abilities (mediated memory, nonverbal spatial thinking, nonverbal imagination) among DE students are also better, but some (effective generalization and verbal-logical thinking) show no significant differences from TE students (Shadrikov et al., 2011). DE students demonstrate a higher level of some mathematical skills (Pavlova, 2008), and also less external motivation and better psychological well-being, but without significant differences in "internal" motivation (Gordeeva et al., 2018). Some of these results are contradictory. In our view, it is more productive to explore those cognitive or personality differences that can be directly related to the specifics of the educational system.

Some empirical studies support this proposition. Thus, Zuckerman and Chudinova showed that fifth-graders in DE are better able to use prompts than TE students (Zuckerman \& Chudinova, 2016). Furthermore, the results of the mathematical subtest of the PISA Program for International Student Assessment show that DE students learn better from previous tasks than TE students (however, this study was not conducted with fourth-graders, but with 15-year-olds) (Zuckerman \& Ermakova, 2004).

So, we suggest that students in a Developmental Education (DE) system may demonstrate better OGK scores than students in a traditional education (TE) system.

\section{Methods}

\section{Participants}

The participants were 115 fourth-graders from one public school in Moscow, 61 boys and 54 girls (average age 10.16, SD 0.46). The participants were divided into two groups: 72 students in TE and 43 in DE.

\section{Materials}

Orientation towards given knowledge (OGK) - method of diagnosis. For our purposes, we chose the action of recognition. The general principles of such diagnostics are described in the works of Talyzina (1975), but we have made some modifications to suit our research objectives.

The participants were given the definition of a concept ("A mammal is an animal that feeds its young with milk") and the following instruction: "You need to 
Table 1

Types of tasks

Type 1. Regular tasks (with all the necessary and sufficient
conditions)

1. Leopard. This is a fast and cautious animal. It has a strong, muscular body. At 5-6 months, after the mother stops nursing the young, she begins to lead them to killed prey.

2. Perch. The perch's body has an oblong shape. The female perch lays up to 800,000 eggs. A fish does not hatch immediately from the egg. First, an embryo develops in it, and it gradually grows and turns into a larva. The larva itself begins to obtain food and soon looks like an adult fish.

3. Bat. Bats are small animals 4 to $16 \mathrm{~cm}$ long. Almost all species of bats produce offspring once a year. Usually they have just one baby. From the moment of birth, the baby feeds on its mother's milk; the period of nursing depends on the type of bat.

4. Whale. Whales are huge marine animals. In cetaceans, the body has the shape of an elongated drop, which makes it easy for them to glide through water. But the baby does not suck milk, like other mammals: When it swims up to its mother's belly, the mother squirts a stream of milk into the baby's mouth.

5. Whale shark. Whale sharks are considered the largest species of fish. Such sharks are ovoviviparous, that is, the young hatch from eggs. After the female has laid her eggs, she leaves her offspring forever and is no longer interested in their fate.

6. Dolphin. The dolphin's body has a fusiform streamlined shape. Almost all members of the dolphin class have a protruding dorsal fin. The skin is elastic and smooth to the touch. A baby dolphin gets food by injection of its mother's milk into its mouth.

\section{Correct \\ answer \\ Correct justification}

$+\quad$ "It feeds its young with milk" / the appropriate words in the text are underlined

- $\quad$ "It does not feed its young with milk" / the appropriate words in the text are underlined

$+\quad$ "It feeds its young with milk" / the appropriate words in the text are underlined

"It feeds its young with milk" / the appropriate words in the text are underlined

- $\quad$ "It does not feed its young with milk" / the appropriate words in the text are underlined

$+\quad$ "It feeds its young with milk" / the appropriate words in the text are underlined

\section{Type 2. Provocative tasks (some necessary conditions are Correct Correct justification lacking) \\ answer}

7. Platypus [Only a picture of the animal was shown]

8. Milk snake. This is a medium-sized, lithe, and mobile snake from $35 \mathrm{~cm}$ to $1.4 \mathrm{~m}$ long, with a slightly pointed, shiny head and convex black eyes. The milk snake hunts at night. Its main food is rodents, usually mice and rats.

9. Cassowary. Cassowary is the Indonesian word for "horned cow". Its length can reach 2 meters, and its weight $85 \mathrm{~kg}$. It is extremely aggressive. With its 20-centimeter claws, a speed on land of $50 \mathrm{k} / \mathrm{h}$, and the ability to swim, a victim has no chance of escape.

10. Bee. Bees are flying insects. In the spring, the queen bee lays her eggs. Young insects feed the queen and all the larvae with a special milk produced in their maxillary glands. First, the queen lays the larva in a wax cell, and then the nurse bees literally "fill" the larva with a nutrient mixture.
? $\quad$ Not enough information

? Not enough information

? Not enough information

? Not enough information 
help a 4-year-old girl find a mammal among the other animals at the zoo, using the short texts that are posted on their enclosures. Select ' + ' if it is a mammal, '-' if not, and '?' if there is not enough information to decide. Please explain all your answers". Two groups of problems were given in random order: (a) problems with all the necessary and sufficient conditions to answer the question (regular tasks), and (b) problems that do not provide all the necessary conditions (provocative tasks). Examples of the problems are presented in Table 1.

Coding of OGK for assessment. We evaluated not so much the correct result that as whether it was justified, based on the given knowledge (the attributes specified in the definition) (see Table 1). If students give the correct answer (“+”, “-”, or "?") and justify it with reference to the given definition in any form (orally or by underlining the key sentence in the texts), we encode it as 1 . If they give the wrong answer, or the correct answer, but justifies it with reference to something else ("I know it", "My Mom told me", etc.), we encode it as 0 . If students give the wrong answer, but justify it with reference to the given definition (for example, "A bee is a mammal because it feeds its young milk), we encode this answer as 0.5. Two experts did the coding, and the correlation between their assessments was 0.98 (Spearman's R-coefficient).

The total OGK was evaluated on a scale of 1 to 10, depending on the number of tasks that were justified, one way or another, by the given knowledge.

We also calculated results according to two separate parameters:

1. OGK in regular tasks (\% of regular tasks in which students use the given definition);

2. OGK in provocative tasks (\% of provocative tasks in which students use the given definition).

Analysis of the reliability of OGKM showed that the Cronbach's alpha coefficient between all 10 problems is 0.909 (the mean Spearman R-coefficient between all problems is 0.508). From this we can conclude that all the tasks measure one meaningful characteristic.

We also evaluated the external validity of the method, comparing the results with another procedure. We used the results of an independent state test for fourth graders ("Diagnostics of Metacognitive Skills in the Field of Mathematics and Natural Sciences", DMSIMS, developed by the Moscow Center for the Quality of Education (Spetsifikatsiya ..., 2019). It assesses the metacognitive skills (cognitive, symbolic, problem-solving, and informational) which should result from studying mathematics and science in elementary school. During this test, the students were given a text and a series of problems to solve after reading a text. The Pearson's correlation of DMSIMS with OGKM is $\mathrm{r}=0.44, \mathrm{p}<0.001$, so we can conclude that the OGKM has sufficient external validity.

Method of diagnosis of the ability to choose the most important thing in a text ("Choice of the main sentences"). The technique was designed specifically for students of grade 4. It is a modification of the "Choice of the main sentences" method designed for high school students by O.E. Malskaya, A.A. Sidel'nikova (Sidel'nikova, 1984; Korotaeva, 2019). We gave the students a text and asked them to "underline the main sentences of this text". Given the students' ages (fourth grade, 10-11 years), the text was not explanatory, as it was when given to high school students, 
but descriptive, citing some facts about the problem and a few "empty" sentences. The criterion for the correctness of the answer was a choice of appropriate definitions and significant facts, rather than statements similar to the definitions, statements about the significance of the problem, etc. (see Table 2). We calculated how many significant sentences each subject selected (a number from 0 to 8 ). We expected that DE students would choose significant sentences more often, and insignificant ones less often.

Table 2

Significant and insignificant sentences in the text ("Choice of the main sentences")

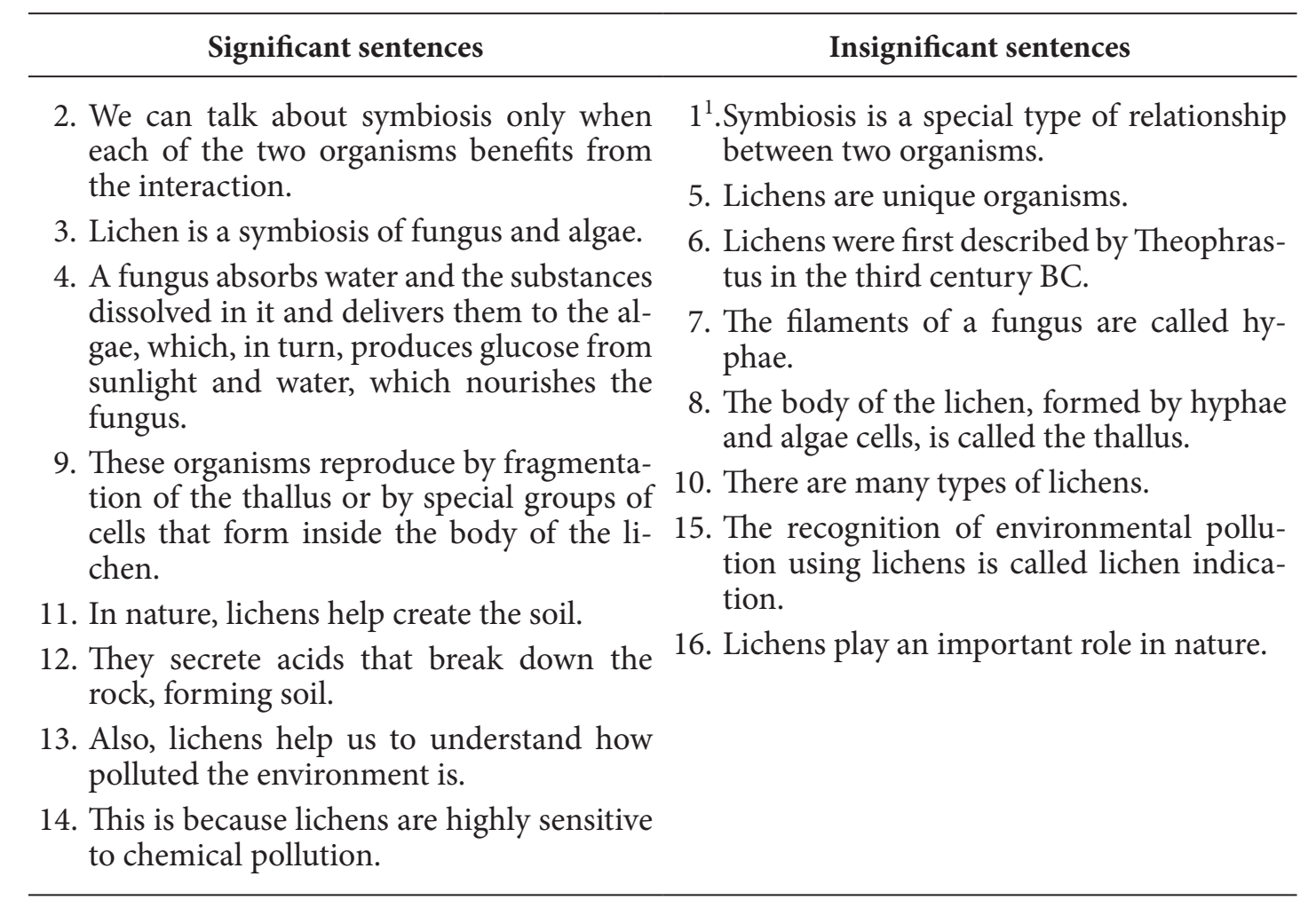

${ }^{1}$ Note. Order of the sentence in the text.

Method of diagnosis of logical skills. We chose only one skill for diagnostic purposes: the ability to find logical (conceptual) connections. This was one of the subtests of the GIT (Group Intelligence Test) (Burlachuk \& Morozov, 2001). The subjects were given two terms in two columns (for example, "February" in the first column and "March" in the second); in the third column there was a term with a different conceptual content (for example, "Tuesday"). Students had to show that they understood the conceptual relationship between the terms in the first two columns by choosing a term from the fourth column that has that same relationship to the term in the third column (in our example, the options were "Sunday", "month", "Wednesday", and "week"). The relationship here is one of sequence - "March" follows "February" - so the correct answer is "Wednesday", which follows "Tuesday". Forty such problems were provided; students could therefore get a maximum of 40 points. We chose this task for the diagnosis of logical skills, since it was important 
for us to check to what extent orientation towards given knowledge is related to the ability to correlate concepts, since this relationship is not obvious (choosing attributes based on a definition and recognizing whether they are present can be done without such a skill, using only the rules of logical inference).

We also used data on the academic achievement of our participants (in mathematics, Russian, and science), with grades on a scale from 2 to 5 .

\section{Data processing}

We used SPSS Statistics 23 for data processing.

\section{Results}

Descriptive statistics for OGK are presented in Table 3.

Table 3

Orientation towards given knowledge: Descriptive statistics

\begin{tabular}{cccccc}
\hline & $\mathrm{N}$ & Minimum & Maximum & Mean & Std. Deviation \\
\hline OGK total & 113 & .00 & 10.00 & 3.96 & 3.39 \\
\hline
\end{tabular}

The distribution of OGK is not normal. As the diagram shows, $25.7 \%$ of the entire sample did not use the given definition (given knowledge) to solve the problems.

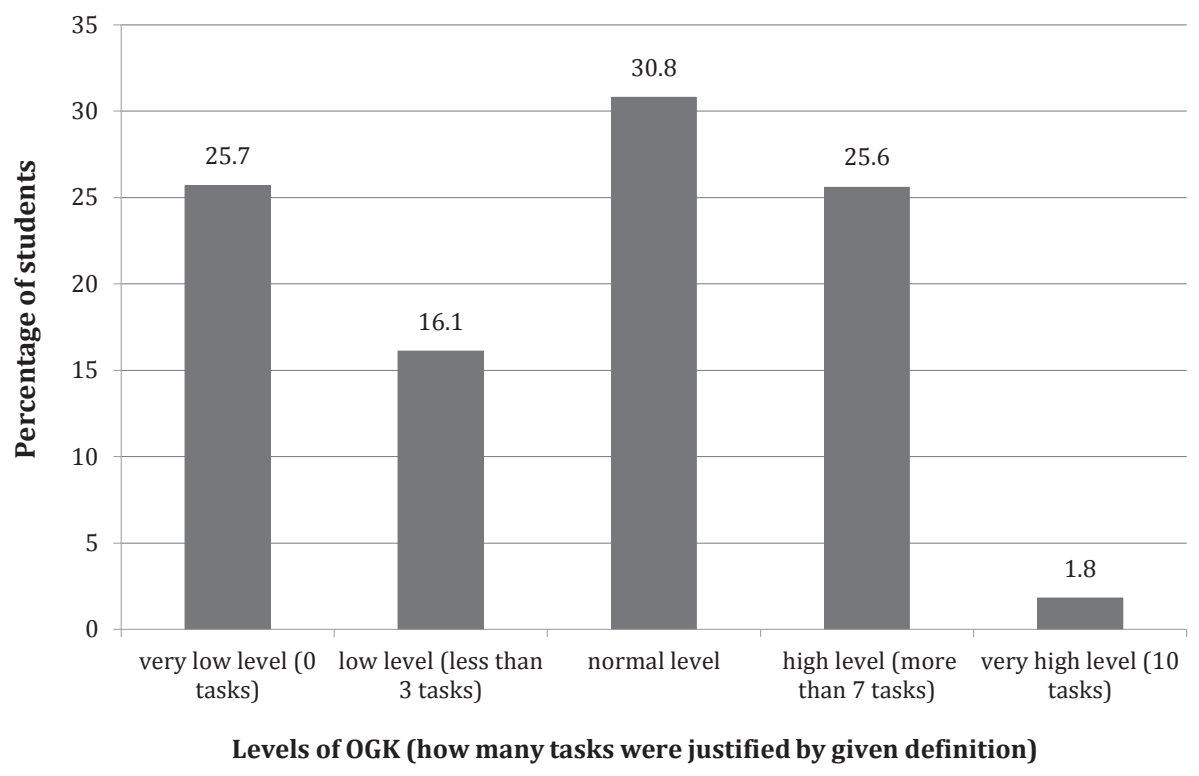

Figure 1. Total distribution of OGK (\% of subjects for each value of the variable)

We also compared OGK for different types of problems (see Table 4). The results show that, as we expected, the regular tasks turned out to be simpler for subjects than more provocative ones (Wilcoxon Signed-Rank Test). 
Table 4

Average percentage of correct answers for each type of task (regular and provocative)

\begin{tabular}{cccc}
\hline & N & Mean & Std. Deviation \\
\hline Regular tasks & 115 & $46.74 \%$ & 40.430 \\
Provocative tasks & 115 & $26.63 \%$ & 31.262 \\
\hline
\end{tabular}

The differences between the two groups of students (TE and DE) were significant (Mann-Whitney criteria for independent samples, $U=2038.5, p<0.01$ ). DE students generally use the definition much more often. Figure 2 shows the percentage of subjects from the $\mathrm{DE}$ and TE groups (relative to the number of subjects in each group) who do not use the definition in every case. The differences between TE and DE are also significant for each type of problem $(U=2104.5, p<.01$ for regular tasks and $\mathrm{U}=2045.0, \mathrm{p}<.01$ for provocative tasks): $\mathrm{DE}$ students often use the given definition to solve problems in both cases.

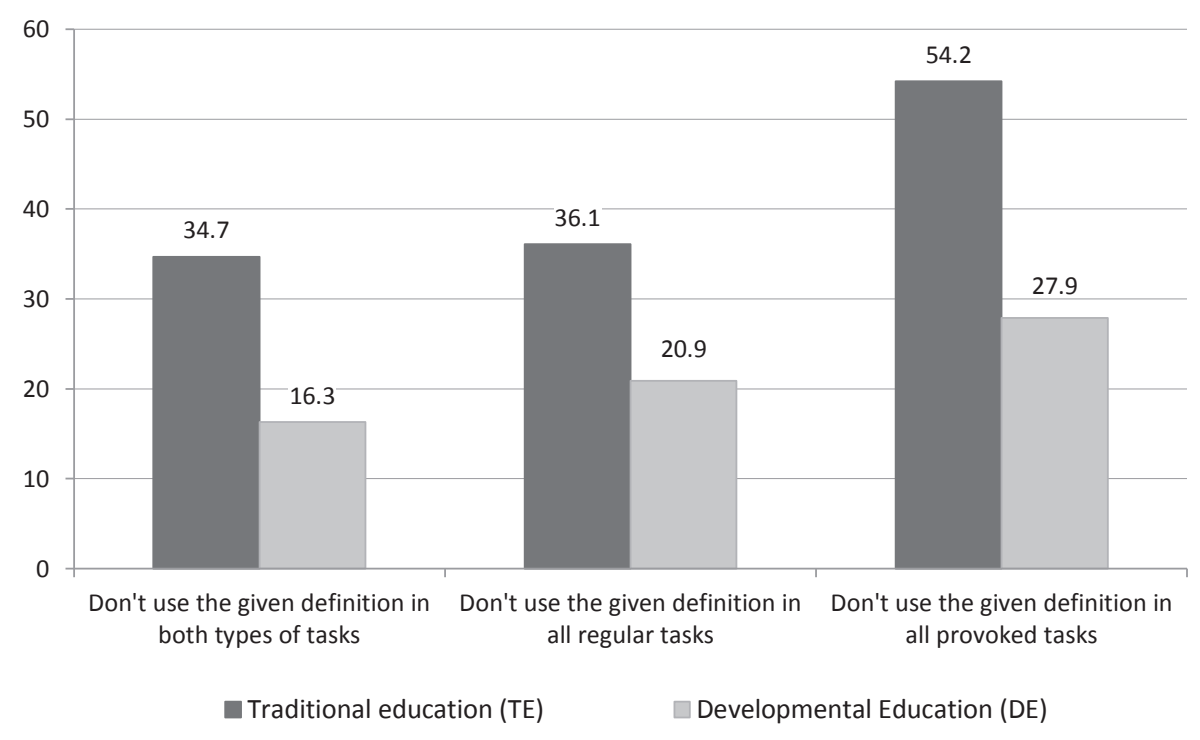

Figure 2. Percentage of subjects in each group who do not use the definition in solving each type of problem.

We used the Spearman R-coefficient to analyze the correlations between OGK and other characteristics. OGK significantly correlates with the ability to underline the most important thing in the text $(\mathrm{R}=+0.345, \mathrm{p}<0.001)$, the ability to correlate concepts $(\mathrm{R}=+0.445, \mathrm{p}<0.001)$ and with memory skills $(\mathrm{R}=+0.195, \mathrm{p}<0.05$ for short-term memory and $\mathrm{R}=+0.301, \mathrm{p}<0.01$ for long-term memory).

It is interesting that TE and DE students do not have significant differences in their ability to correlate concepts and in their memorization skills (according to the Mann-Whitney $U$ criterion ). There are differences only in the ability to correctly underline the main sentences in the text $(U=1870.5, p<0.05$; $D E$ is significantly better). 
OGK also correlates with academic achievement, but only in mathematics $(\mathrm{r}=+0.22, \mathrm{p}<0.05)$ and Russian $(\mathrm{r}=+0.18, \mathrm{p}<0.05)$. We found no significant connection with academic achievement in science.

\section{Discussion}

Students confront definitions of concepts every day at school. More often than not, after defining a new concept and providing the necessary explanations, the teacher requires students to be able to solve problems using this definition. As our study shows, some students (about 25 percent) not only do not understand how to use the definition to solve the problem, but even that it should be used at all. When we talk about OGK and its purpose in instruction, we mean perceiving any knowledge as a tool for possible future actions, and also the ability to rely on given rules and definitions for independent problem solving. Interestingly, we can "notice" such inability only in the conditions of the first type of OBA (according to Gal'perin) - in a situation, where students should search not only for the points of orientation but sometimes the actions too. This poses a very crucial problem not only for primary schoolchildren, but also for undergraduate students: Most of them believe that definitions should simply be memorized in order to reproduce them later (Korotaeva, 2019).

One possible explanation for the results we obtained is that our participants (like most fourth graders) simply do not possess the ability to recognize a definition as a "conceptual" way of classifying objects, and do not realize that once that ability is formed, there will be no problem with orientation towards given knowledge. This is partly true, but in our view, it is only the technical side of the problem. What is important for us is how concepts and their definitions function, how they establish the specificity of the learning process as an assimilation of culture - orientation towards given knowledge versus orientation towards something else, to particular attributes of objects included in definitions, or to extraneous attributes.

If we analyze the internal structure of the action of recognition itself, we find that it is one of the few ways to deal with real objects insofar as they "belong" to a certain concept, with everything that "lies behind" it, the whole complex of mental functions that require mastery of the knowledge in question. If the students properly master this activity, it will not just "come in handy", but will turn out to be a real working tool for mastering given knowledge, as conceptual mediation in solving problems in a given subject. The resulting ability to orient towards given knowledge can be meaningfully considered as a prerequisite for effective learning activity, since many of the actions that are part of the learning process - comparison, classification, etc. - are not about specific information, but general mental processes.

Why did the DE students demonstrate higher levels of OGK than TE students? Comparing the principles and methods by which learning activity is organized in these two educational programs, we note that in DE, particular attention is given to models for solving subject-matter problems (Davydov, 1996; Repkina, 1997). In the DE curricula, the students' ability to switch from the model to the real situation that it describes is directly or indirectly tested and diagnosed. Apparently, the modeling skills acquired in problem solving allow children to learn how to perceive the subject matter, and, accordingly, the given knowledge, from the standpoint of 
its general orienting functions in the environment. Such an orienting function of the given knowledge is considered by Gal'perin as the key characteristic of the third type of OBA (in comparison with the second type of OBA) (Gal'perin, 1966, p. 266).

It is interesting to compare our results with those of other diagnostic studies of students in various educational systems. Even in comparative studies of DE and TE-students based on comparing components of theoretical thinking such as ability to find a general method of solving tasks (see, for example, Zak, 1990; Rubtsov at al. 2019), some of them tried to find differences in ability to learn from given knowledge. One example is a relatively recent publication by G.A. Zuckerman and E.V. Chudinova (Zuckerman \& Chudinova, 2016), on students' ability to meaningfully use short textual prompts in solving problems. This study found that fifthgraders in DE use prompts significantly better than TE students. The ability of students aged 14-15 to learn from previous tasks was evaluated by the PISA methods (Zuckerman \& Ermakova, 2004), and with similar results: The DE students showed a higher level of development of this ability. Interestingly, the DE and TE students did not show significant differences in more traditional cognitive and metacognitive characteristics (IQ, memory, attention, and so on [Shadrikov, 2011]). From this we can conclude that the difference between the two groups is a result of the curriculum, and that, in comparing educational systems overall, subtle differences in the results should be taken into account.

Another interesting result of our study is that OGK is positively correlated with the ability to find significant sentences in the text. There are many studies in cognitive psychology that show that even with clear procedural knowledge of the subject, students have difficulty using it to solve problems, which researchers generally attribute to a lack of certain metacognitive factors, such as metacognitive regulation of cognitive processes (Kendeou, van den Broek, Helder, \& Karlsson, 2014; Duke \& Pearson, 2009).

A more complex situation is presented by the possibility of performing actions related to the given concepts, based on what has been read. Interestingly, the establishment of semantic links in the text is significantly improved when the students are invited to ask questions about this text (independently or from a general list of questions) (King, 1994; Oleynikova, 2012). In our view, when students ask questions, it prompts them to find situations and actions for which the information given in the text could become a point of departure, positively affecting their understanding of what was written.

Thus, students' lack of typical learning skills (with an emphasis on the main ones: systematization, generalization, etc.) can be directly interpreted as a lack of OGK, specifically in relation to the perception of knowledge as providing points of orientation and the ability to discover actions that correspond to given knowledge as an orienting "tool". Thus, students' lack of learning skills in working with texts (underlining the main point, systematization, summarizing, etc.) can be understood as a lack of OGK, including the perception of knowledge as providing orientation and the ability to choose actions that are appropriate to the given knowledge. No wonder there is quite a high correlation between OGK in recognition of concepts and in text comprehension. It is also interesting that OGK correlates with academic achievement, but only in Mathematics and Russian as school subjects, but not in Science. Perhaps this can be explained by the grading system: Science 
is usually not considered an important subject in elementary school, and in most cases students are given quite high grades.

What is the importance of the results of our OGK research for issues of modern educational psychology? Of course, some of them can be described in the traditional terms of metacognitive skills. Metacognition concerns descriptive knowledge of and operational control over one's cognitive processes (Veenman, 2015). Another area of research into similar phenomena is the study of conceptual changes (Posner, Strike, Hewson, \& Gertzog 1982; Vosniadou, 2013). Resistance to conceptual changes can be associated with the inability of students to relate the knowledge they have gained to their own actions. Often this is associated with the formation of meta-learning: students' theories about their learning and approaches to learning (Entwistle, 2000). So, with a "superficial" approach, the student perceives learning as memorizing the facts and reproducing them, referring to this knowledge as something that simply needs to be reproduced. But with a "deep" approach, the text is understood from the point of view of the connections it suggests: a specific system that directly corresponds to the meta-disciplinary structures of knowledge.

However, "resistance to conceptual changes" can be, in our view, more constructively understood as the students' inability to connect their knowledge with their own actions. Accordingly, the student has an opportunity to discover the necessary actions and their elements in the text. If the psychological mechanisms of orientation towards given knowledge are not formed, then this material will not be sought by the students. But, according to our assumption, problems of metacognition or meta-learning in education can be considered as an attempt to avoid changing the content and methods of education (this is the key point for the Activity Approach). The traditional solution of problems of superficial approaches to learning is to immediately create a new curriculum (for example, courses in logic, metacognitive skills, etc.), whereas the formation of this key metacognitive ability may, in all likelihood, be much more closely associated with a change in the content and teaching methods along the lines of the Activity Approach in educational psychology and didactics. So, we prefer to think of OGK not as a separately acquired ability, but as an essential condition for and product of Developmental Education.

\section{Conclusions}

The problem of applying knowledge to problem solving is one of the key issues in modern educational psychology. In this article, we suggest that this problem arises in children because they cannot "see" the future action that underlies the definition of the concept and for which the attributes of the concept will serve as a means (in the terminology of L. S. Vygotsky).

This ability, which we call "orientation towards given knowledge", distinguishes, as our study showed, students in the El'konin-Davydov educational system from students in the traditional system. As we also have shown, orientation towards given knowledge is closely related to the ability to underline the main sentences in a text, and this can be explained by the fact that underlining the main sentences is closely associated with the ability to formulate the key questions that the text answers (also the ability to see the actions "behind" the given knowledge). In sum, 
orientation towards given knowledge can be considered an essential condition for learning and one of the most relevant issues for modern pedagogical psychology.

\section{Acknowledgment}

The study was supported by the Russian Foundation of Fundamental Investigations (RFFI No. 19-013-00717).

\section{References}

Anderson, L.W., \& Krathwohl, D.R. et al. (Eds.) (2001). A taxonomy for learning, teaching, and assessing: A revision of Bloom's taxonomy of educational objectives. Boston, MA: Allyn \& Bacon (Pearson Education Group).

Aydarova, L.I. (1968). Formirovanie nekotorykh ponyatii grammatiki po tretemu tipu orientirovki $\mathrm{v}$ slove [Formation of some of the concepts of grammar in the third type of orientation in the word]. In P.Ya. Gal'perin and N.F. Talyzina (Eds.) Zavisimost' obucheniya ot tipa orientirovki [Dependence of teaching on the type of orienting activity] (pp. 42-80). Moscow: MGU Publ.

Barnett, S.M., \& Ceci, S.J. (2002). When and where do we apply what we learn? A taxonomy for far transfer. Psychological Bulletin, 128(4), 612-637. https://doi.org/10.1037/0033-2909.128.4.612

Bloom, B.S., Englehard, M.D., Furst, E.J., \& Hill, W.H. (1956). Taxonomy of educational objectives: The classification of educational goals: Handbook I, cognitive domain. London (pp. 1-207). https://doi. org/10.1300/J104v03n01_03

Burlachuk, 1.F., \& Morozov, S.M. (1989). Slovar'-spravochnik po psikhologicheskoy diagnostike [Dictionary of psychological diagnostics]. Kiev, USSR: Nauk Dumka.

Davydov, V.V. (1996). Teoriya razvivayushchego obucheniya [Theory of developmental education]. Moscow: INTOR.

Davydov, V.V. (1995). The influence of L.S. Vygotsky on education theory, research and practice. Educational Researcher, 24(3), 12-21. https://doi.org/10.3102/0013189X024003012

Duke, N.K., \& Pearson, P.D. (2009). Effective Practices for developing reading comprehension. Journal of Education, 189(1-2), 107-122. https://doi.org/10.1177/0022057409189001-208

El'konin, D.B. (1966). Intellektual'nye vozmozhnosti mladshikh shkol'nikov i soderzhanie obucheniya [Intellectual abilities of primary school children and teaching content]. In D.B. El'konin and V.V. Davydov (Eds.), Vozrastnye vozmozhnosti usvoeniya znanii (mladshie klassy shkoly) [Age-related opportunities for learning (primary school)] (pp. 13-53). Moscow: Prosveschenie.

Entwistle, N.J. (2000). Approaches to studying and levels of understanding: The influences of teaching and assessment. In J.C. Smart (Ed.), Higher education: Handbook of theory and research (Vol. 15, pp. 156-218). New York: Agathon Press.

Gal'perin, P.Ya. (1989). Organization of mental activity and the effectiveness of learning. Soviet Psychology, 27(3), 65-82. https://doi.org/10.2753/RPO1061-0405270365

Gal'perin, P.Ya. (1966). Psikhologiya myshleniya i uchenie o poetapnom formirovanii umstvennykh deystvii [Psychology of thinking and theory about the gradual formation of mental actions]. In E.V. Shorohova (Ed.), Issledovaniya myshleniya v sovetskoy psikhologii (pp. 236-277). Moscow: Nauka.

Gal'perin, P.Ya, \& Talyzina, N.F. (1957). Formirovanie nachalnykh geometricheskikh ponyatii na osnove organizovannykh deystvii uchashchikhsya [The formation of initial geometric concepts based on organized actions of students]. Voprosy psikhologii [Psychological issues], 1, 28-44.

Gordeeva, T.O., Sychev, O.A., Pshenichnuk, D.V., \& Sidneva, A.N. (2018). Academic motivation of elementary school children in two educational approaches - innovative and traditional. Psychology in Russia: State of the Art, 11(4), 19-36. https://doi.org/10.11621/pir.2018.0402

Ilyenkov, E.V. (1991). Deiatel'nost' i znanie [Activity and knowledge]. In Filosofiya i kul'tura [Philosophy and culture]. Moscow: Politizdat. 
Kendeou, P., van den Broek, P., Helder, A., \& Karlsson, J. (2014). A cognitive view of reading comprehension: Implications for reading difficulties. Learning Disabilities Research \& Practice, 29(1), 10-16. https://doi.org/10.1111/ldrp.12025

King, A. (1994). Guiding knowledge construction in the classroom: Effects of teaching children how to question and how to explain. American Educational Research Journal, 31(2), 338-368. https:// doi.org/10.3102/00028312031002338

Korotaeva, I.V. (2019). Orientirovka v strukture nauchnogo znaniya kak osnova umeniya uchit'sya $\mathrm{u}$ studentov raznykh spetsializatsii [Orientation in the structure of scientific knowledge as the basis of the ability of students of different specializations to learn]. Vestnik Moskovskogo universiteta. Seriya 14. Psikhologiya [Moscow University Psychology Bulletin], 2, 88-104. https://doi.org/10.11621/vsp.2019.02.88

Leontiev, A.N. (2005). The fundamental processes of mental life. Journal of Russian \& East European Psychology, 43(4), 72-75. https://doi.org/10.1080/10610405.2005.11059259

L’vovskii, V.A., Morozova, A.V., \& Uliashev, K.D. (2015). Deiatel'nostnyi podkhod k perepodgotovke uchitelei [The Activity Approach to teachers' education]. Moscow: Avtorskii klub.

Morosanova, V.I., \& Aronova, E.A. (2004) Razvivayushchee i traditsionnoe obrazovanie: effekty v lichnostnom razvitii starsheklassnikov [Developmental and traditional education: Effects in the personal development of high school students]. Psikhologicheskaya nauka i obrazovanie [Psychological science and education], 1, 42-54.

Oleynikova, Ye. V. (2012). Vliyanie podkhoda $k$ ucheniyu u shkolnikov na ponimanie uchebnykh tekstov [The influence of the approach to learning on schoolchildren's understanding of educational texts]. PhD Thesis. Moscow: Lomonosov Moscow State University. http://www.psy.msu.ru/science/autoref/oleynikova.pdf

Pavlova, V.V. (2008). Sravnityelnyy analiz innovatsionnykh tekhnologii obuchyeniya s pozitsii dyeyatyelnostnogo podkhoda [Comparative analysis of innovative learning technologies from the standpoint of the activity approach]. PhD Thesis. Moscow: Lomonosov Moscow State University.

Posner, G. J., Strike, K. A., Hewson, P. W., \& Gertzog, W. A. (1982). Accommodation of a scientific conception: Toward a theory of conceptual change. Science Education, 66(2), 211-227. https://doi.org/10.1002/sce.3730660207

Radford, L. (2013). Three key concepts of the theory of objectification: Knowledge, knowing, and learning. Journal of Research in Mathematics Education, 2(1), 7-44. https://www.researchgate. net/publication/277967414_Three_Key_Concepts_of_the_Theory_of_Objectification_Knowledge_Knowing_and_Learning\#fullTextFileContent

Repkina, N.V. (1997). Sistema razvivayushchego obucheniya v shkolnoy praktike [The developmental education system in school practice]. Voprosy psikhologii [Psychological Issues], 3, 40-50.

Rubtsov, V.V. , Vysotskaia, E.V., Zak, A.Z., Ianishevskaia, M.A., \& Ulanovskaia, I.M. (2019). Dinamika metapredmetnykh rezul'tatov nachal'nogo obrazovaniya na etape perekhoda $\mathrm{v}$ osnovnuyu shkolu [Dynamics of the meta-subject results of primary education at the stage of transition to primary school]. Psikhologiia. Zhurnal Vysshei Shkoly Ekonomiki, 16(3), 511-528. https://doi.org/10.17323/1813-8918-2019-3-511-528

Shadrikov, V.D., Zinovieva, N.A., \& Kuznetsova, M.D. (2011). Razvitie mladshikh shkol'nikov v razlichnykh obrazovatel'nykh sistemakh [Primary schoolchildren's development in different educational systems]. Moscow: LOGOS.

Sidelnikova, A.A. (1984). Osobennosti osoznaniya uchebnoy deyatelnosti [Features of awareness of educational activities]. Undergraduate Thesis. Moscow: Facultet psikhologii MGU.

Sidneva, A.N. (2016). Problema ucheniya v pedagogicheskoi psikhologii: dialektika estestvennogo i normativnogo [The problem of learning in educational psychology: The dialectics of the natural and normative]. Voprosy psikhologii [Psychological Issues], 1, 79-85.

Spetsifikatsiya proverochnoy raboty dlya diagnostiki metapredmetnykh (poznavatelnykh) umenii v oblasti estestvoznaniya i matematiki v 4 klassakh obshcheobrazovatelnykh organizatsii g. Moskvy 31 yanvarya 2019 g. https://mcko.ru/uploads/mpn-4_spetsifikatsiya_i_demoversiyaa38964914f38629b.pdf (accessed on 14 May 2019). 
Steffens, K. (2015). Competences, learning theories and MOOCs: Recent developments in lifelong learning. European Journal of Education, 50(1), 41-59. https://doi.org/10.1111/ejed.12102

Stepanova, M.A. (2005). Psikhologicheskii analiz pedagogicheskogo protsessa (na primere shkol'nogo kursa lingvistiki) [Psychological analysis of the pedagogical process (for example, the school linguistics course)]. Psikhologicheskaya nauka i obrazovanie [Psychological Science and Education], $4,5-13$.

Talyzina, N.F. (1975). Upravlenie protsessom usvoeniya znanii [Managing the process of knowledge assimilation]. Moscow: MGU Publ.

Ten Berge, T., \& Van Hezewijk, R. (1999). Procedural and declarative knowledge: An evolutionary perspective. Theory \& Psychology, 9(5), 605-624. https://doi.org/10.1177/0959354399095002

Veenman, M.V.J. (2015). Teaching for metacognition. International Encyclopedia of the Social \& Behavioral Sciences (Second Edition), pp. 89-95. https://doi.org/10.1016/B978-0-08-097086-8.92136-6

Vosniadou, S. (2013). Conceptual change research: An introduction. In S. Vosniadou (Ed.), International handbook of research on conceptual change. New York: Routledge. https://doi.org/10.4324/9780203154472

Vygotsky, L.S. (1978). Mind in society: The development of higher psychological processes. M. Cole, V. John-Steiner, S. Scribner, \& E. Souberman, Eds. Cambridge, MA: Harvard University Press.

Zak, A.Z. (1990). Formirovanie psikhicheskikh novoobrazovanii v uchebnoi deiatel'nosti [The formation of mental neoformations in learning activity]. In V.V.Davydov (Ed.), Psikhicheskoe razvitie mladshikh shkolnikov [Mental development of primary schoolchildren]. Moscow: Pedagogika.

Zukerman, G.A., \& Chudinova, E.V. (2016). Diagnostika umeniya uchit'sya [Diagnostics for learning skills]. Moscow: Author's Club.

Zukerman, G.A., \& Ermakova, I.V. (2004). Razvivayushchie effekty sistemy D.B. El'konina V.V. Davydova: vzglyad so storony kompetentnostnogo podkhoda [Developmental effects of the D.V. El'konin-V.V. Davydova system: a view from the competence approach]. Psikhologicheskaya nauka i obrazovanie [Psychological Science and Education], 4, 56-73.

Zukerman, G.A., \& Venger, A.L. (2010) Razvitie uchebnoi samostoiatel'nosti sredstvami shkol'nogo obrazovaniya [The development of academic independence through school education]. Psikhologicheskaya nauka i obrazovanie [Psychological Science and Education], 4, 77-90.

Original manuscript received July 09, 2019

Revised manuscript accepted March 05, 2020

First published online June 15, 2020

To cite this article: Sidneva, A.N., Vysotskaya, E.V., Korotaeva, I.V., Mozharovsky, I.L., Shinelis, V.A. How Do Primary Schoolchildren Use Concept Definitions in Recognition Tasks? Orientation Towards Given Knowledge in Two Different Educational Systems. Psychology in Russia: State of the Art, 13(2), 29-46. DOI: 10.11621/pir.2020.0203 